\title{
Protein-calorie malnutrition: Effect of deficient diets on enzyme levels of jejunal mucosa of rats
}

\author{
Bx G. SOLIMANO*, E. ANN BURGESS AND B. LEVIN \\ Queen Elizabeth Hospital for Children, Hackney Road, London, E 2
}

(Received 25 April I966-Accepted I8 August 1966)

\begin{abstract}
I. The effects of low-protein and protein-free diets on the levels of disaccharidase, peptidase and aldolase activities in the jejunal mucosa of rats were studied.

2. Maltase, palatinase and sucrase activities increased significantly after both types of feeding, although there was an initial fall with the protein-free diet.

3. The rise in lactase levels was, however, not so marked.

4. Glycyl-glycine and glycyl-leucine dipeptidase levels fell consistently with both diets.

5. Aldolase activities were generally unaltered, but tended to fall if the period of low-protein feeding was prolonged.

6. Enzyme levels rapidly returned to normal when the rats were given a normal diet after a period on a protein-deficient one.

7. It is suggested that the rise in disaccharidase and fall in peptidase levels are adaptive changes to the high-carbohydrate, low-protein diet, with diminished enzyme synthesis, due to lack of nitrogen, contributing to the lowered peptidase activities. The relevance of these results to disaccharide intolerance in chronic malnutrition, kwashiorkor and gastro-intestinal infection is discussed.
\end{abstract}

The syndromes resulting from protein-calorie malnutrition in early childhood have been extensively studied in recent years, especially in the extreme form of kwashiorkor. Since this is primarily a protein-deficiency disease, attention has been mainly on protein metabolism and few investigations have been made on carbohydrate metabolism. According to Dean (1952), lactose intolerance with diarrhoea occurs in kwashiorkor, and Bowie, Brinkman $\&$ Hansen (1963) have suggested that other disaccharides may also be poorly tolerated. This is supported by the findings of Stanfield, Hutt \& Tunnicliffe (1965) who have shown diminished disaccharidase activity in the jejunal mucosa of children with kwashiorkor.

Gastro-intestinal infection superimposed on malnutrition may be a prime factor in causing disaccharide intolerance, and diarrhoea itself may result in a temporary intolerance to lactose, sucrose or starch. Diarrhoea due to failure to hydrolyse dietary disaccharides is well known as a congenital disorder in infants and children. This failure is due to an inherited deficiency of one of the disaccharide-splitting enzymes known to be present in the intestinal mucosa. It is probable that the disaccharide intolerance resulting from gastro-intestinal infection is also due to a decrease in the disaccharidase activity of the small intestine. Disaccharide intolerance in proteincalorie malnutrition may therefore result from either malnutrition or gastro-intestinal infection or both together. This investigation was initiated in an attempt to assess separately the influence of these two factors on enzyme activities of the jejunal mucosa. Since malnourished children were not available for study and it would not in any case

* Present address: 'A' Department of Pediatrics, Hospital 'Roberto del Rio', and School of Public Health, Faculty of Medicine, University of Chile, Santiago, Chile. 
be possible to isolate these two factors in the human infant, it was decided to simulate the condition of the malnourished child in the rat. The present article describes the disaccharidase, dipeptidase, and aldolase activities of the jejunal mucosa of rats fed on low-protein and protein-free diets compared with those fed on a 'normal diet'. The results are also reported on malnourished rats after refeeding on the 'normal' diet for varying periods.

\section{EXPERIMENTAL}

\section{Animals and their treatment}

Female Wistar albino rats were used in all experiments. For enzyme estimations of jejunal mucosa in the normal rat, three age-groups were used: (I) young adults, 60-90 days old, mean weight $206 \mathrm{~g}$, (2) 47 days old, mean weight $48 \mathrm{~g}$, and (3) 32 days old, mean weight $42 \mathrm{~g}$. This normal group of twenty-one rats was killed after periods varying from $I$ to 30 days on a 'normal' diet.

To simulate as closely as possible the conditions in the human malnourished child, the rats on the experimental low-protein diets were selected from the age group just after weaning, taken to be at 28 days of age. The group of fifteen rats (mean weight $37 \mathrm{~g}$ ) on the protein-free diet was first fed on this diet at $3 \mathrm{I}$ days old, and groups were killed 7,14 , and 22 days afterwards. The groups of fourteen rats placed on a low-protein diet from $3^{1}$ days (mean weight $39 \mathrm{~g}$ ) and 45 days (mean weight $63 \mathrm{~g}$ ) were killed 22, 44 , and 66 days afterwards.

Table I. Composition of diets

\begin{tabular}{lcccc}
\multicolumn{1}{c}{ Diet } & $\begin{array}{c}\text { Farlene (see below) } \\
\text { (parts by } \\
\text { weight) }\end{array}$ & $\begin{array}{c}\text { Cornflour } \\
\text { (parts by } \\
\text { weight) }\end{array}$ & $\begin{array}{c}\text { Protein } \\
(\%)\end{array}$ & NDpCal \% \\
Normal & 100 & 150 & 10 & 8 \\
Low-protein & 100 & 400 & 5 & 5 \\
Protein-free & 0 & 100 & 0.4 & $<0.4$
\end{tabular}

\section{Diets}

Three different diets were used. For simplicity these were made up from varying proportions of Farlene Infant Food (Farley Ltd, Plymouth) and maize starch (cornflour) (Table I). Farlene is a proprietary prepared infant food containing $25 \%$ protein, 6I $\%$ carbohydrate (lactose $5 \%$, sucrose $5 \%$, starch $5 \mathrm{I} \%$ ) and $5.5 \%$ fat, together with added minerals and vitamins. The diets were given ad lib. The 'normal' diet was so considered because it afforded normal growth, weight gain, and reproduction in rats (P. R. Payne, personal communication), and this diet is meant when a normal diet is mentioned hereafter. No minerals or vitamins were added either to the low-protein or the protein-free diet. In consequence, the latter diet especially was markedly deficient not only in protein, but also in vitamins and minerals.

The protein value of each diet was calculated as net dietary protein calories $\%$ (NDpCal \%) according to the formula of Miller \& Payne (196r). 


\section{Preparation of mucosal homogenates}

Rats were always starved overnight, and killed by a blow on the neck after light anaesthesia. When possible, blood was immediately taken from the heart for estimation of serum protein.

In order to determine whether there was any significant variation in enzyme activities in different portions of the small intestine, two segments, each $10 \mathrm{~cm}$ in length, were examined. The first was taken commencing at a distance of $10 \%$ of the total length of the intestine from pylorus to the ileo-caecal junction; the second was cut at a distance of $35 \%$ of the total length. Later, only the second segment was analysed, as this showed the higher level of enzyme activity.

The $10 \mathrm{~cm}$ length of intestine was placed immediately in ice-cold $0.9 \% \mathrm{NaCl}$ solution to prevent excessive drying. It was then transferred to filter paper and opened longitudinally. Washing with saline after opening the bowel was not found necessary. The mucosa was removed with a scalpel, weighed and homogenized in water, a $\mathrm{I} \mathrm{ml}$ all-glass Ten Broek homogenizer being used. About fifteen strokes of the plunger were sufficient to produce adequate homogenization. The initial concentration taken was $I$ in 40 . A small specimen of intestine from the same site was always taken for histological examination.

\section{Disaccharidases}

\section{Estimation of enzyme activities}

These were measured by the method of Burgess, Levin, Mahalanabis \& Tonge (1964).

Aldolase (ketose-I-phosphate aldehyde-lyase, EC 4.1.2.7. and fructose-1,6-diphosphate D-glyceraldehyde-3-phosphate-lyase, EC 4.1.2.13.)

Principle. The trioses formed by cleavage of fructose-r-phosphate or fructose-I, 6-diphosphate by aldolase were measured as the dinitrophenylhydrazones, which give in alkaline solution a blue colour read at $570 \mathrm{~nm}$.

Procedure. For the assay, a $\mathrm{I}$ in 100 homogenate of intestinal mucosa in water was used. Enzyme activity was usually determined within $24 \mathrm{~h}$, but the suspension retained full activity for at least $I$ month if kept at $-18^{\circ}$.

$0.1 \mathrm{ml}$ of homogenate was mixed with $0.05 \mathrm{ml}$ of the appropriate substrate $(0.126$ M-fructose-I-phosphate or $0.04 \mathrm{M}$-fructose- I,6-diphosphate) and $0.2 \mathrm{ml}$ of a buffer solution containing I. I ml $0.2 \mathrm{M}$-tris buffer $\mathrm{pH} 8.6,0 . \mathrm{I} \mathrm{ml} 0.56 \mathrm{M}$-hydrazine hydrate $\mathrm{pH} 8.5,0.3 \mathrm{ml} .8 \mathrm{~mm}$-sodium iodoacetate and $0.5 \mathrm{ml}$ of water. The reaction mixture was incubated at $37^{\circ}$ and $0.05 \mathrm{ml}$ portions were taken into $0.05 \mathrm{ml}$ of $7 \%$ perchloric acid at $0,10,20$ and $30 \mathrm{~min}$. After centrifugation, samples of $0.05 \mathrm{ml}$ of the supernatant liquid were removed and $0.05 \mathrm{ml}$ of $0.75 \mathrm{~N}$-sodium hydroxide was added. The mixture was allowed to stand for exactly $10 \mathrm{~min}$ at room temperature, after which $0.05 \mathrm{ml}$ of a solution of 2,4 -dinitrophenylhydrazine in $2 \mathrm{~N}-\mathrm{HCl}(\mathrm{I} \mathrm{mg} / \mathrm{ml})$ was added. The tubes were left at room temperature for approximately $45 \mathrm{~min}$, and then to each was added $0.5 \mathrm{ml}$ of a solution of $2 \mathrm{~N}$-sodium hydroxide ( $\mathrm{I}$ vol.) in methyl cellosolve (2 vol.). After approximately $30 \mathrm{~min}$ the colour was read at $570 \mathrm{~nm}$. 
The method was standardized by estimation of the alkali-labile phosphorus with a liver homogenate with both fructose-I-phosphate and fructose-I,6-diphosphate as substrates. A factor was then calculated relating the optical density of the phenylhydrazones in the method given, with the same liver homogenate, to the concentration of trioses as found from the alkali-labile phosphorus.

\section{Glycyl-glycine hydrolase (EC 3.4.3.I) and glycyl-L-leucine hydrolase (EC 3.4.3.2)}

Principle. The amount of dipeptide hydrolysed by the enzyme present in the homogenate was measured by the increase in substances producing a colour with ninhydrin during incubation in presence of the appropriate metal cofactor.

Procedure. For rats on a normal diet, $\mathrm{I}$ in I6o homogenates of intestinal mucosa were used; for the rats on the low-protein or protein-free diet, $r$ in 80 homogenates were prepared.

$25 \mu \Gamma^{5}$ of homogenate, $5 \mu \Gamma^{\circ}$ of $0.4 \mathrm{M}$-borate buffer $\mathrm{pH} 7 \cdot 7,5 \mu \Gamma^{\circ}$ of $0.01 \mathrm{M}-\widehat{C o C T}_{2}$, and $5 \mu \mathrm{l}$ water were incubated at $37^{\circ}$ for $10 \mathrm{~min}$ in each of two tubes. To one, Io $\mu \mathrm{l}$ of $0.125 \mathrm{M}$-glycyl-glycine were added, the second serving as a control. Both tubes were incubated for a further $45 \mathrm{~min}$ at $37^{\circ}$; to each were then added $0.25 \mathrm{ml} 6 \%$ trichloroacetic acid, followed by 10 $\mu \mathrm{l}$ of the glycyl-glycine solution to the control only. After centrifuging, $0.1 \mathrm{ml}$ of the supernatant liquid was added to $0.24 \mathrm{ml}$ water. After treatment with ninhydrin reagent (Moore \& Stein, I948) the optical density was read at $570 \mathrm{~nm}$ and compared with a standard curve prepared from mixtures of dipeptide and amino acid treated with ninhydrin reagent.

For glycyl-leucine, $\mathrm{x}$ M-phosphate buffer $\mathrm{pH} 7.7$ and $0.0 \mathrm{I} \mathrm{M}-\mathrm{MnCl}_{2}$ were used instead of borate buffer and $\mathrm{CoCl}_{2}$.

Results are expressed as $\mu$ moles dipeptide split per $\mathrm{h}$ per mg wet weight mucosa.

In a small number of rats the dipeptidase levels were determined by the method of Josefsson (1964).

\section{Serum protein estimation}

Total serum protein and albumin were determined by the micro-Kjeldahl method (Levin, Oberholzer \& Whitehead, 1950). For the albumin determination, 22.5\% sodium sulphate solution was used as precipitant.

\section{RESULTS}

Fig. I shows the relation between the mean weights of the groups of rats fed on the normal, low-protein and protein-free diets and the duration of feeding. Rats on the low-protein diet gained weight at a consistently lower rate than those fed on the normal diet, and those on the protein-free diet lost weight throughout.

It was observed that rats on the low-protein diet usually showed a patchy but severe loss of hair after 22 days. When these animals were again given the normal diet, the hair began to grow. Rats on the protein-free diet did not show this loss, probably because of the shorter duration of feeding, but after 22 days several showed oedema of the legs and some ascites. This could be correlated with the low levels of total serum 
protein in this group, a mean value of $3.06 \mathrm{~g} / 100 \mathrm{ml}$ compared with a mean value of $5.85 \mathrm{~g} / \mathrm{I} 00 \mathrm{ml}$ for the group fed on the low-protein diet for 44 days, and with the mean of $6.58 \mathrm{~g} / 100 \mathrm{ml}$ (albumin $3.95 \mathrm{~g}$, globulin $2.62 \mathrm{~g} / 100 \mathrm{ml}$ ) for the normal animals.

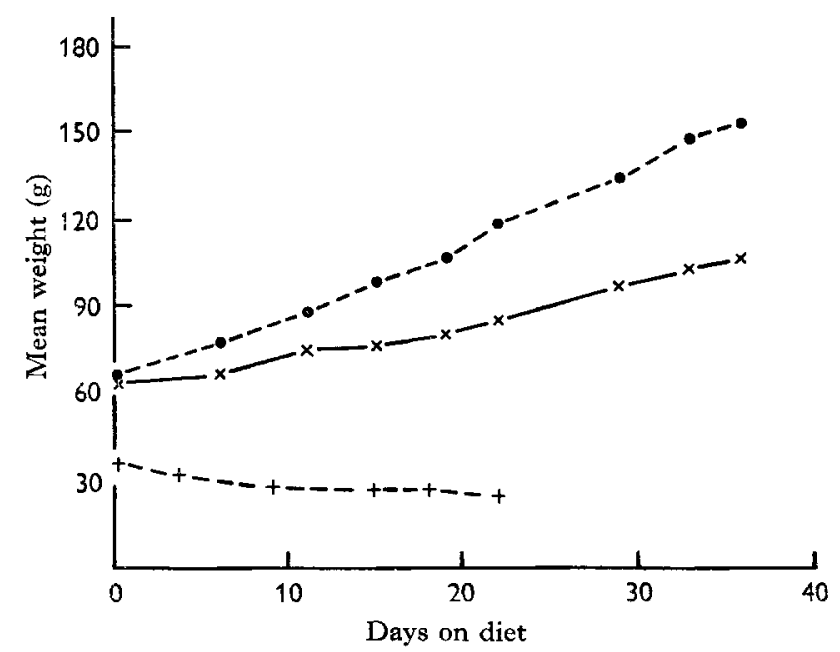

Fig. I. Mean weight gains of rats fed on a normal (O), a low-protein $(x)$ or a protein-free $(t)$ diet.

Table 2. Enzyme activities in jejunal mucosa of rats fed on normal diet

\begin{tabular}{|c|c|c|c|}
\hline Enzyme & No. of rats & Mean value and SD & Range \\
\hline $\begin{array}{l}\text { Disaccharidase* } \\
\text { Lactase } \\
\text { Maltase } \\
\text { Palatinase } \\
\text { Sucrase }\end{array}$ & $\begin{array}{l}2 I \\
2 I \\
20 \\
2 I\end{array}$ & $\begin{array}{l}1 \cdot 91 \pm 0.77 \\
33.6 \pm 7 \cdot 1 \\
1 \cdot 99 \pm 0.68 \\
10.3 \pm 3.2\end{array}$ & $\begin{array}{l}0.55-3 \cdot 66 \\
23 \cdot 6-46 \cdot 2 \\
0.8 I-3.33 \\
5 \cdot 6-x 8.6\end{array}$ \\
\hline $\begin{array}{l}\text { Aldolase } \dagger \\
\text { Fructose- } 1 \text {-phosphate }(a) \\
\text { Fructose-1,6-diphosphate }(b) \\
\text { Ratio, } a: b\end{array}$ & $\begin{array}{l}2 I \\
2 I\end{array}$ & $\begin{array}{l}I \cdot 98 \pm I \cdot 2 I \\
3 \cdot 66 \pm I \cdot 97 \\
I \cdot 92\end{array}$ & $\begin{array}{l}0.58-5 \cdot 85 \\
I \cdot 3 I-8 \cdot 57 \\
r \cdot 28-3 \cdot 10\end{array}$ \\
\hline $\begin{array}{l}\text { Dipeptidaset } \\
\text { Glycyl-glycine } \\
\text { Glycyl-leucine }\end{array}$ & $\begin{array}{l}16 \\
14\end{array}$ & $\begin{array}{l}4.95 \pm 3.53 \\
13.4 \pm 10.2\end{array}$ & $\begin{array}{l}0.20-14.10 \\
0.5-39.0\end{array}$ \\
\hline
\end{tabular}

Enzyme levels in jejunal mucosa of rats on normal diet

Since there was no significant difference in the enzyme levels of rats of various ages from 32 to 90 days and fed on our normal diet for periods varying from $r$ to $3^{\circ}$ days, all these results were combined. Table 2 shows the mean values, ranges and standard deviations for aldolase, the two dipeptidases, glycyl-glycine and glycylleucine and the disaccharidases, lactase ( $\beta$-D-galactoside galactohydrolase, $\mathrm{EC}_{3.2 .1 .23}$ ), maltase ( $\alpha$-D-glucoside glucohydrolase EC 3.2.I.20), palatinase or isomaltase (oligodextrin 6-glucanohydrolase, $\mathrm{EC}$ 3.2.1.I0) and sucrase ( $\beta$-D-fructofuranoside fructohydrolase, EC 3.2.1.26). 
The range of levels was rather wide for all the disaccharidases except maltase. The values obtained for lactase were considerably lower than those for rats before weaning (Alvarez \& Sas, I96I). The levels of disaccharidase activities in the two segments of jejunal mucosa in a group of ten rats were compared. As judged by the $t$ test, both lactase and maltase were significantly higher in the distal segment, whereas there was no significant difference in either palatinase or sucrase.

The levels of aldolase in rat intestinal mucosa have not previously been determined. It is interesting to note that the aldolase activity (Table 2) was somewhat higher than in human intestinal mucosa (Burgess \& Levin, I 965 , unpublished). The aldolase activity with fructose-I,6-diphosphate as substrate is higher than with fructose-I-phosphate as substrate and the ratio of the activities is approximately 2 to $\mathrm{I}$, a value agreeing with that found in human intestinal mucosa (Burgess \& Levin, 1965, unpublished), and similar to that found in human and mouse liver, but much lower than the ratio in human muscle or in serum.

For the dipeptidases, glycyl-glycine and glycyl-leucine, which have not previously been measured in rat jejunal mucosa, the range of values was wide, as has also been noted for the dipeptidases of pig intestinal mucosa (Josefsson \& Lindberg, $1965 a, b$ ), but most fell within a relatively narrow range, with only one or two results falling well outside it.

\section{Enzyme levels in jejunal mucosa of rats fed on a low-protein or a protein-free diet}

In order to determine the effect of duration of feeding with the experimental lowprotein and protein-free diets as well as the effect of the normal diet on mucosal enzyme activities, three groups of rats on each diet were studied. Disaccharidase, aldolase and dipeptidase levels were measured in rats fed on the low-protein diet for 22, 44 and 66 days respectively. The latter diet could not be tolerated by rats for much longer than 22 days.

The results for the individual enzymes in the groups of rats fed on the two different diets are shown in Tables 3-7. For comparison, each table includes the relevant values for rats fed on the normal diet. Each mean was individually compared with the normal mean value by Student's $t$ test. For the assessment of the significance of the varying duration of feeding in each group of rats on a low-protein or a protein-free diet, an analysis of variance was performed.

Lactase (Table 3). The mean values for lactase in both the low-protein and the protein-free diets with the different durations of feeding showed no significant differences from the normal when the $t$ test was applied. Although the differences between the subgroups caused by duration of feeding on the protein-free diet were not statistically significant, there was a marked fall in the mean value at $\mathrm{I}_{4}$ days, and this activity rose at $\mathbf{2 2}$ days to a level higher than the normal.

Maltase and palatinase (Table 4). The mean values for maltase and palatinase in both the low-protein and protein-free diets revealed significant differences from the normal and also for the varying periods of time.

For the protein-free diet, the mean levels of maltase after 7 days were not different 
from the normal. After 14 days, however, the levels fall sharply to approximately $50 \%$ of the normal, but after $\mathbf{2 2}$ days they rose to nearly three times the value at 14 days, and $50 \%$ above the normal mean, these differences being highly significant. The mean levels for the palatinase followed a similar pattern, except that the changes were not quite so marked.

\section{Table 3. Effect of variation of protein intake and duration of feeding on lactase activity in jejunal mucosa of rats}

(Mean values with standard deviations and ranges)

\begin{tabular}{|c|c|c|c|}
\hline Diet & $\begin{array}{c}\text { Days on } \\
\text { diet }\end{array}$ & $\begin{array}{l}\text { No. of } \\
\text { rats }\end{array}$ & Lactase activity* \\
\hline Protein-free $(\mathrm{NDpCal} \%<0.4)$ & $\begin{array}{r}7 \\
14 \\
22\end{array}$ & $\begin{array}{l}4 \\
4 \\
7\end{array}$ & $\begin{array}{l}\mathrm{I} \cdot 85 \pm 0.8 \mathrm{I}(\mathrm{I} \cdot \mathrm{I} 2-2 \cdot 59) \\
\mathrm{I} \cdot \mathrm{I} \pm 0.53(0.58-\mathrm{I} \cdot 68) \\
2 \cdot 5 \mathrm{I} \pm \mathrm{I} \cdot 30(\mathrm{I} \cdot \mathrm{I} 7-4.3 \mathrm{I})\end{array}$ \\
\hline Low-protein (NDpCal \% = 5) & $\begin{array}{l}22 \\
44 \\
66\end{array}$ & $\begin{array}{l}4 \\
7 \\
3\end{array}$ & $\begin{array}{l}I \cdot 70 \pm 0 \cdot 45(I \cdot 16-2 \cdot 28) \\
2 \cdot 18 \pm 0 \cdot 75(I \cdot 35-3 \cdot 36) \\
2 \cdot 09 \pm 0 \cdot 73(I \cdot 49-2 \cdot 9 r)\end{array}$ \\
\hline Normal (NDpCal \% = 8) & $I-30$ & $2 \mathrm{I}$ & $1.91 \pm 0.77(0.55-3.66)$ \\
\hline
\end{tabular}

Table 4. Effect of variation of protein intake and duration of feeding on maltase and palatinase activities in jejunal mucosa of rats

(Mean values with standard deviations and ranges)

\begin{tabular}{|c|c|c|c|c|}
\hline Diet & $\begin{array}{c}\text { Days on } \\
\text { diet }\end{array}$ & $\begin{array}{c}\text { No. of } \\
\text { rats }\end{array}$ & Maltase activity $\dagger$ & Palatinase activity $\dagger$ \\
\hline $\begin{array}{l}\text { Protein-free } \\
(\text { NDpCal } \%<0.4)\end{array}$ & $\begin{array}{r}7 \\
14 \\
22\end{array}$ & $\begin{array}{l}4 \\
4 \\
7\end{array}$ & $\begin{array}{l}33.7 \pm 13.4(20 \cdot 4-47.5) \\
19.0 \pm 6.9 * *(13.0-27 \cdot 5) \\
51.4 \pm I I \cdot 8 * *(37 \cdot 7-70.6)\end{array}$ & $\begin{array}{l}2 \cdot 27 \pm 0.75\left(\mathrm{r} \cdot 57-3 \cdot 1_{5}\right) \\
I \cdot 61 \pm 0.56\left(\mathrm{I} \cdot 08-2 \cdot \mathrm{I}_{5}\right) \\
2 \cdot 84 \pm 0.70(1 \cdot 72-3 \cdot 7 \mathrm{I})\end{array}$ \\
\hline $\begin{array}{l}\text { Low-protein } \\
\qquad(\mathrm{NDpCal} \%=5)\end{array}$ & $\begin{array}{l}22 \\
44 \\
66\end{array}$ & $\begin{array}{l}4 \\
7 \\
3\end{array}$ & $\begin{array}{l}32 \cdot 4 \pm 3 \cdot 8(29 \cdot 9-38 \cdot 1) \\
45 \cdot 0 \pm 4 \cdot 4^{* *}\left(38 \cdot 3-49^{\cdot} 2\right) \\
35^{\circ} 4 \pm 9^{\circ} 5\left(24 \cdot 4-4 I^{\circ} 0\right)\end{array}$ & $\begin{array}{l}I \cdot 89 \pm 0.20(1 \cdot 66-2 \cdot 16) \\
2 \cdot 71 \pm 0.62 *(2 \cdot 0-3 \cdot 45) \\
2 \cdot 76 \pm 0.74(2 \cdot 22-3 \cdot 52)\end{array}$ \\
\hline Normal (NDpCal \% = 8) & $I-30$ & $2 \mathrm{I}$ & $33 \cdot 6 \pm 7 \cdot 1(23 \cdot 6-46 \cdot 2)$ & $I .99 \pm 0.68(0.8 I-3.33)$ \\
\hline
\end{tabular}

Significance of differences between means of normal and experimental diets: $0.01<P<0.05$; ** $P<0.01$.

Significance of differences according to duration of feeding: (r) maltase-protein-free diet, $P<0.01$; (2) maltase-low-protein diet, $P<0.01$; (3) palatinase-protein-free diet, $P<0.05$; (4) palatinase-low-protein diet, $0.01<P<0.05$.

+ Unit $=$ I $\mu$ mole substrate split/g wet weight per min.

For the rats on the low-protein diet, mean levels of both maltase and palatinase in the group fed for 22 days were not significantly different from the normal means. It is interesting to note that the activity of these two enzymes in jejunal mucosa of the rats fed on a protein-free diet for the same period of time was very much greater. In the rats fed on the protein-free diet for a period of 44 days, the maltase and palatinase levels rose steeply and significantly to approximately $50 \%$ above their values at 22 days. After 66 days, however, the maltase activity had again fallen to the normal activity, although the palatinase level remained the same as after 44 days on the low-protein diet. 
Sucrase (Table 5). Like the other disaccharidases, the mean level of sucrase in rats fed on a protein-free diet was not significantly different from the normal at 7 days but fell by about $30 \%$ at 14 days. There was again a rise to about $50 \%$ above the normal after 22 days on this diet. An analysis of variance showed that the difference between the mean levels for the different periods of feeding were highly significant.

For the low-protein diet, there was, as in maltase and palatinase levels, a highly significant increase in sucrase activity of about $50 \%$ and significant rises in maltase and palatinase activities in the group fed for 44 days over that fed for only 22 days, whose levels were the same as those in normal rats. The levels of sucrase and maltase, however, fell to the mean normal after 66 days on this diet.

\section{Table 5. Effect of variation of protein intake and duration of feeding on} sucrase activities in jejunal mucosa of rats

(Mean values with standard deviations and ranges)

\begin{tabular}{|c|c|c|c|}
\hline Diet & $\begin{array}{c}\text { Days on } \\
\text { diet }\end{array}$ & $\begin{array}{c}\text { No. of } \\
\text { rats }\end{array}$ & Sucrase activity $\dagger$ \\
\hline Protein-free (NDpCal $\%<0.4$ ) & $\begin{array}{r}7 \\
14 \\
22\end{array}$ & $\begin{array}{l}4 \\
4 \\
7\end{array}$ & 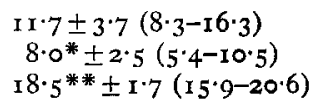 \\
\hline Low-protein (NDpCal $\%=5$ ) & $\begin{array}{l}22 \\
44 \\
66\end{array}$ & $\begin{array}{l}4 \\
7 \\
3\end{array}$ & $\begin{array}{l}10.7 \pm 1 \cdot 3(10.0-12 \cdot 7) \\
16.5 * \pm \pm 3.1(13.6-22 \cdot 0) \\
10.3 \pm 1.8(8.7-12.3)\end{array}$ \\
\hline Normal (NDpCal $\%=8)$ & $1-30$ & $2 \mathrm{r}$ & $10.3 \pm 3 \cdot 2(5 \cdot 6-18 \cdot 6)$ \\
\hline
\end{tabular}

Significance of differences between means of normal and experimental diets: $* 0.01<P<0.05$; *** $P<0.01$;

Significance of differences according to duration of feeding: (I) protein-free diet, $P<0.01$; (2) lowprotein diet, $P<0.01$ ).

+ Unit $=$ I $\mu$ mole substrate split/g wet weight per min.

Aldolase (Table 6). For the rats on a protein-free diet there was no significant difference between the aldolase activities for both fructose- I-phosphate and fructoseI,6-diphosphate in the animals fed on this diet for 7, 14 and 22 days compared with mean normal levels. The enzyme levels were higher after 14 and 22 days on the proteinfree diet than on the normal diet, but this difference disappears if two rats, one in each subgroup, which had levels more than three times the normal, are excluded from the comparison.

In the rats receiving the low-protein diet, the activities of both aldolases were lower than the normal mean, both at 22 and 44 days, but this difference was only significant at the $5 \%$ level as judged by the $t$ test. However, at 66 days, the levels rose to the normal value. One animal in this group also had very high activities, and if these are excluded, the value would have been as low at 66 as after 22 and 44 days.

Dipeptidases (Table 7). Although for the protein-free diet, the dipeptidase activities showed neither a statistically significant difference from the mean normal nor a significant change with duration of feeding, the mean level for glycyl-glycine dipeptidase was reduced at $\mathrm{I} 4$ days, and fell to about $50 \%$ of the normal after 22 days. For glycylleucine dipeptidase the fall was less, to about $80 \%$. 
After 44 days on the low-protein diet, glycyl-glycine dipeptidase activity decreased significantly $(P<0.0 \mathrm{r})$. This difference did not exist after 66 days. Examination of the individual results in the latter group shows, however, that two animals had no detectable dipeptidase activity, and one had a very high value, so that the mean level at this time appeared the same as that after 22 days. Although the differences were not statistically significant, the dipeptidase activities after 22 days on the low-protein diet were low, about $50 \%$ of the normal mean. Other differences in dipeptidase activity were not significant.

Table 6. Effect of variation of protein intake and duration of feeding on fructose I-phosphate and fructose-1,6-diphosphate aldolase activities in jejunal mucosa of rats

$$
\text { (Mean values with standard deviations and ranges) }
$$

\begin{tabular}{|c|c|c|c|c|}
\hline Diet & $\begin{array}{l}\text { Days on } \\
\text { diet }\end{array}$ & $\begin{array}{l}\text { No. of } \\
\text { rats }\end{array}$ & $\begin{array}{l}\text { Fructose-I-phosphate } \\
\text { aldolase activity } \dagger\end{array}$ & $\begin{array}{l}\text { Fructose-r,6-diphosphate } \\
\text { aldolase activity } t\end{array}$ \\
\hline $\begin{array}{l}\text { Protein-free } \\
(\text { (NDpCal } \%<0.4)\end{array}$ & $\begin{array}{r}7 \\
14 \\
22\end{array}$ & $\begin{array}{l}4 \\
4 \\
7\end{array}$ & $\begin{array}{l}I \cdot 04 \pm 0.47(0 \cdot 78-1 \cdot 75) \\
3 \cdot 11 \pm x \cdot 90(1 \cdot 56-5 \cdot 85) \\
2 \cdot 84 \pm 2.08(1 \cdot 36-7 \cdot 42)\end{array}$ & $\begin{array}{l}2.22 \pm 0.8 \mathrm{r}(\mathrm{x} \cdot \mathrm{x}-3.13) \\
6.09 \pm 4.42(3.29-12.69) \\
4.97 \pm 4.08(2.06-13.68)\end{array}$ \\
\hline $\begin{array}{l}\text { Low-protein } \\
(\text { NDpCal } \%=5)\end{array}$ & $\begin{array}{l}22 \\
44 \\
66\end{array}$ & $\begin{array}{l}4 \\
7 \\
3\end{array}$ & $\begin{array}{l}0.77 \pm 0.27^{*}(0.39-0.97) \\
0.93 \pm 0.40^{*}(0.39-1.46) \\
2.04 \pm 1.94(0.87-4.29)\end{array}$ & $\begin{array}{l}I \cdot 93 \pm 0.45(\mathrm{I} \cdot 48-2 \cdot 47) \\
2 \cdot 01 \pm 0.68^{*}(0.90-2 \cdot 96) \\
4.72 \pm 3.90(2 \cdot 30-9.23)\end{array}$ \\
\hline Normal (NDpCal $\%=8$ ) & $I-30$ & $2 \mathbf{I}$ & $I \cdot 98 \pm I \cdot 21(0 \cdot 58-5 \cdot 85)$ & $3 \cdot 66 \pm I \cdot 97(1 \cdot 3 \mathrm{I}-8 \cdot 57)$ \\
\hline
\end{tabular}

Significance of differences between means of normal and experimental diets: * $0.01<P<0.05$. $\dagger$ Unit $=1 \mu$ mole substrate split $/ \mathrm{g}$ wet weight per min.

Table 7. Effect of variation of protein intake and duration of feeding on glycylglycine and glycyl-leucine dipeptidase activities in jejunal mucosa of rats

(Mean values with standard deviations and ranges)

\begin{tabular}{|c|c|c|c|c|c|}
\hline \multirow[b]{2}{*}{ Diet } & \multirow[b]{2}{*}{$\begin{array}{l}\text { Days on } \\
\text { diet }\end{array}$} & \multicolumn{2}{|c|}{$\begin{array}{l}\text { Glycyl-glycine } \\
\text { dipeptidase }\end{array}$} & \multicolumn{2}{|c|}{$\begin{array}{l}\text { Glycyl-leucine } \\
\text { dipeptidase }\end{array}$} \\
\hline & & $\begin{array}{l}\text { No. of } \\
\text { rats }\end{array}$ & Activity† & $\begin{array}{l}\text { No. of } \\
\text { rats }\end{array}$ & Activity \\
\hline $\begin{array}{l}\text { Protein-free } \\
(\text { NDpCal } \%<0.4)\end{array}$ & $\begin{array}{r}7 \\
14 \\
22\end{array}$ & $\begin{array}{l}4 \\
4 \\
7\end{array}$ & $\begin{array}{l}4 \cdot 6 \pm I \cdot 5(3 \cdot 2-6 \cdot 9) \\
3 \cdot 4 \pm 2 \cdot 3(0 \cdot 0-5 \cdot 4) \\
2 \cdot 6 \pm 1 \cdot 2(1 \cdot 2-5 \cdot 3)\end{array}$ & $\begin{array}{l}3 \\
3 \\
7\end{array}$ & $\begin{array}{l}13 . x \pm 5.0(8.5-18.6) \\
11.9 \pm 9.5(4.1-22.6) \\
10.7 \pm 6.4(1.4-17.4)\end{array}$ \\
\hline $\begin{array}{l}\text { Low-protein } \\
(\text { NDpCal \% = 5) }\end{array}$ & $\begin{array}{l}22 \\
44 \\
66\end{array}$ & $\begin{array}{l}4 \\
7 \\
3\end{array}$ & $\begin{array}{l}2.4 \pm 2.1(0.0-4.9) \\
0.8 \pm 0.4 *(0.0-1 \cdot 2) \\
2.5 \pm 4.3(0.0-7.6)\end{array}$ & $\begin{array}{l}4 \\
6 \\
3\end{array}$ & $\begin{array}{l}5.0 \pm 4.9\left(0.0-1 I^{2}\right) \\
6.3 \pm 3.9(1.0-10.3) \\
7.3 \pm 12.6(0.0-21.9)\end{array}$ \\
\hline $\begin{array}{l}\text { Normal } \\
(\mathrm{NDpCal} \%=8)\end{array}$ & $I-30$ & 16 & $4.9 \pm 3.5(0.2-14.1)$ & 14 & $13.4 \pm 10.2(0.5-39 \cdot 0)$ \\
\hline
\end{tabular}

Significance of differences between means of normal and experimental diets: $*<0.0$. $\dagger$ Unit $=$ I $\mu$ mole substrate split/mg wet weight per $h$.

Enzyme levels in jejunal mucosa of rats receiving a normal diet after a period of protein depletion

It was of interest to determine whether the enzyme changes produced after feeding rats on a protein-deficient diet could be reversed on return to a normal diet. A group of twelve rats was first fed on the low-protein diet for 44 days; subgroups consisting of 
four animals were subsequently given the normal diet for 7,14 and 22 days respectively, after which time the enzyme levels of the jejunal mucosa were estimated in the usual way. The results are shown in Table 8, which also shows enzyme activities after 44 days on the low-protein diet and mean normal values. It is interesting that, for the disaccharidases, the enzyme activities fell from the previously high values to approximately the normal level after the normal diet had been given for 7 days; there was no further significant change after 14 and 22 days.

Table 8. Enzyme activities in jejunal mucosa of rats fed on normal diet following a protein-deficient diet

(Mean values and standard deviations)

\begin{tabular}{|c|c|c|c|c|c|c|}
\hline \multirow[b]{2}{*}{ Diet } & \multirow{2}{*}{$\begin{array}{l}\text { Days } \\
\text { on diet }\end{array}$} & \multirow{2}{*}{$\begin{array}{l}\text { No. of } \\
\text { of rats }\end{array}$} & \multicolumn{4}{|c|}{ Disaccharidase* } \\
\hline & & & Lactase & Maltase & Palatinase & Sucrase \\
\hline $\begin{array}{l}\text { Normalf } \\
\text { Low-protein }\end{array}$ & $\frac{1}{44}$ & $\begin{array}{l}t \\
7\end{array}$ & $\begin{array}{l}1 \cdot 91 \pm 0.77 \\
2 \cdot 18 \pm 0.75\end{array}$ & $\begin{array}{l}33 \cdot 6 \pm 7 \cdot 1 \\
45 \cdot 0 \pm 4 \cdot 4\end{array}$ & $\begin{array}{l}1.99 \pm 0.68 \\
2.71 \pm 0.62\end{array}$ & $\begin{array}{l}10.3 \pm 3.2 \\
16.5 \pm 3 \cdot 1\end{array}$ \\
\hline \multirow[t]{3}{*}{$\begin{array}{l}\text { Normal, after } \\
\text { low-protein }\end{array}$} & $\begin{array}{c}7 \\
14 \\
22\end{array}$ & $\begin{array}{l}3 \\
4 \\
4\end{array}$ & $\begin{array}{l}I \cdot 71 \pm 0.90 \\
I \cdot 73 \pm 0.66 \\
I \cdot 89 \pm 0.35\end{array}$ & $\begin{array}{l}35 \cdot 8 \pm 7 \cdot 4 \\
43 \cdot 8 \pm 5 \cdot 4 \\
36 \cdot 9 \pm 3 \cdot 9\end{array}$ & $\begin{array}{l}2 \cdot 18 \pm 0.48 \\
I \cdot 94 \pm 0.40 \\
2 \cdot 17 \pm 0.33\end{array}$ & $\begin{array}{l}10 \cdot 6 \pm 1 \cdot r \\
16 \cdot 0 \pm 4 \cdot 6 \\
I 1 \cdot 6 \pm 2 \cdot 3\end{array}$ \\
\hline & & & \multicolumn{2}{|c|}{ Aldolase* } & \multicolumn{2}{|c|}{ Dipeptidase $\dagger$} \\
\hline & & & $\begin{array}{l}\text { Fructose-r- } \\
\text { phosphate }\end{array}$ & $\begin{array}{l}\text { Fructose-I, } \\
\text { 6-diphosphate }\end{array}$ & $\begin{array}{l}\text { Glycyl- } \\
\text { glycine }\end{array}$ & $\begin{array}{l}\text { Glycyl- } \\
\text { leucine }\end{array}$ \\
\hline $\begin{array}{l}\text { Normal } \neq \\
\text { Low-protein }\end{array}$ & $\begin{array}{r} \pm \\
44\end{array}$ & $\begin{array}{l}t \\
7\end{array}$ & $\begin{array}{l}I \cdot 98 \pm I \cdot 2 I \\
0.93 \pm 0.40\end{array}$ & $\begin{array}{l}3.66 \pm 1.97 \\
2.01 \pm 0.68\end{array}$ & $\begin{array}{l}4.9 \pm 3.5 \\
0.8 \pm 0.4\end{array}$ & $\begin{array}{c}13.4 \pm 10.2 \\
6.3 \pm 3.9\end{array}$ \\
\hline $\begin{array}{l}\text { Normal, after } \\
\text { low-protein }\end{array}$ & $\begin{array}{r}7 \\
14 \\
22\end{array}$ & $\begin{array}{l}3 \\
4 \\
4\end{array}$ & $\begin{array}{l}0.90 \pm 0.31 \\
I .55 \pm 2.10 \\
2.87 \pm 1.54\end{array}$ & $\begin{array}{l}3.51 \pm 0.91 \\
3.23 \pm 2.63 \\
6.33 \pm 4.03\end{array}$ & $\begin{array}{l}2 \cdot 7 \pm 2 \cdot 7 \\
3 \cdot 8 \pm 3 \cdot 6 \\
7 \cdot 2 \pm 4 \cdot 4\end{array}$ & $\begin{array}{l}5 \cdot 8 \pm 5 \cdot 6 \\
17 \cdot 0 \pm 12 \cdot 5 \\
25 \cdot 9 \pm 5 \cdot 2\end{array}$ \\
\hline
\end{tabular}

The changes in aldolase activity were somewhat different. There was no alteration in the low activity with fructose-I-phosphate as substrate after 7 days, but the level rose to nearly normal after 14 days, and exceeded it after 22 days. On the other hand, within 7 days there was a rise in the activity with fructose-1,6-diphosphate as substrate to the level found in normal rats, and a rise to even higher activities at 22 days.

There was a marked recovery in glycyl-glycine dipeptidase activity after 7 days refeeding on a normal diet, and still further recovery after 14 and 22 days, when the level was, in fact, higher than the normal. The level of glycyl-leucine dipeptidase showed, however, little change after 7 days, but rose markedly after $1_{4}$ days, and greatly exceeded the normal value after 22 days refeeding on a normal diet.

\section{DISCUSSION}

The factors which give rise to disaccharide intolerance in malnourished children are as yet poorly understood. Enzyme deficiency is known to be a cause of an inability to absorb dietary disaccharides, and a few recent investigations have supported the suggestion that this may be an important factor in the causation of food intolerance in 
malnourished children. Although Dean (1952) had earlier noted the occurrence of lactose intolerance in kwashiorkor, and had claimed to control the diarrhoea by a lowcarbohydrate, high-protein diet, more definite evidence was provided by Cevini, Giovannini \& Careddu (1962). These authors showed, in a group of ten chronically malnourished infants, that after the administration of disaccharide, in particular lactose, the blood sugar failed to rise, there was acid diarrhoea and the carbohydrate was excreted in the stools. They thought that this was due to a deficiency of disaccharidases in the intestinal mucosa. This has also been suggested by Bowie et al. (1963) who found that, in protein-calorie malnutrition, dietary restriction of carbohydrate resulted in a marked decrease in stool weight per day and in stool lactic acid content. They also postulated that the enzyme deficiency was due to protein depletion. Their group of thirteen infants included five who had definite evidence of gastrointestinal infection; but no comment was made by Cevini et al. (1962) on the presence or absence of infection in their group.

The evidence that disaccharide intolerance in protein-calorie malnutrition is due to enzyme deficiency in the intestinal mucosa is therefore indirect and scanty. More direct evidence has recently been provided by Stanfield $e$ t al. (1965). They determined the disaccharidase levels in peroral biopsy specimens of jejunal mucosa from nine children with kwashiorkor of whom four were untreated and five had been treated for a year, and noted a marked decrease in some disaccharidase activities compared with normal values. The biochemical changes in their children were associated with flattening and diminution of the villi resembling those found in the malabsorption syndrome.

Little is known about the effect of protein-calorie deficiency on the enzymes of the intestinal mucosa of animals. Heard (1957) found that the concentration of the dipeptidase, prolidase, in the intestinal mucosa of pigs was reduced when the animals were fed on a protein-free diet. Platt, Heard \& Stewart ( 1964$)$ noted that, in pigs fed on a low-protein diet, the jejunal mucosa showed a marked flattening and widening of the villi, again similar to changes found in malabsorption syndromes. There is no information on the speed with which enzyme activity of the intestinal mucosa recovers when children with kwashiorkor are given normal diets, nor for protein-calorie deficient animals.

The results obtained in this investigation do not support the suggestion that disaccharidase intolerance in protein-calorie malnutrition results from decreased enzyme activities in the jejunal mucosa-if we may apply the results for rats directly to children. The maltase, palatinase and sucrase levels increased significantly after feeding on a low-protein or protein-free diet although this increase was not nearly so marked for lactase (Tables $3-5$ ). These results can be most readily explained by postulating that the high proportion of dietary starch needing maltase and isomaltase (palatinase) for the final cleavage of this carbohydrate before intestinal absorption leads to an adaptive increase in enzyme activity. Such adaptation of enzyme activity is a property of many organs. The amount of lactose present in the protein-deficient diets was relatively small, so that it would not be expected to produce as marked an increase in the corresponding enzyme. 
In all instances the disaccharidase activities tended to fall initially with proteinIfree feeding before the increase occurred. The requirement of the intestine for nitrogen is the highest among the organs of the body (Done \& Payne, 1959) and the replacement rate of the epithelial cells of the intestinal tract is also very high $-\mathbf{r} \cdot 35$ days in the rat (Leblond \& Stevens, 1948). It seems reasonable to assume that the initial fall in enzyme activities is due to protein deficiency, and that the rise which occurs thereafter is an adaptive change resulting from the diversion of nitrogen to the needs of essential enzyme synthesis. When protein deficiency was not so severe, as in the rats fed on the low-protein diet, this initial fall was not observed, either because sufficient nitrogen was always available for the increased synthesis of essential enzymes, or because the fall may have occurred before the earliest estimations of intestinal enzyme activity were performed.
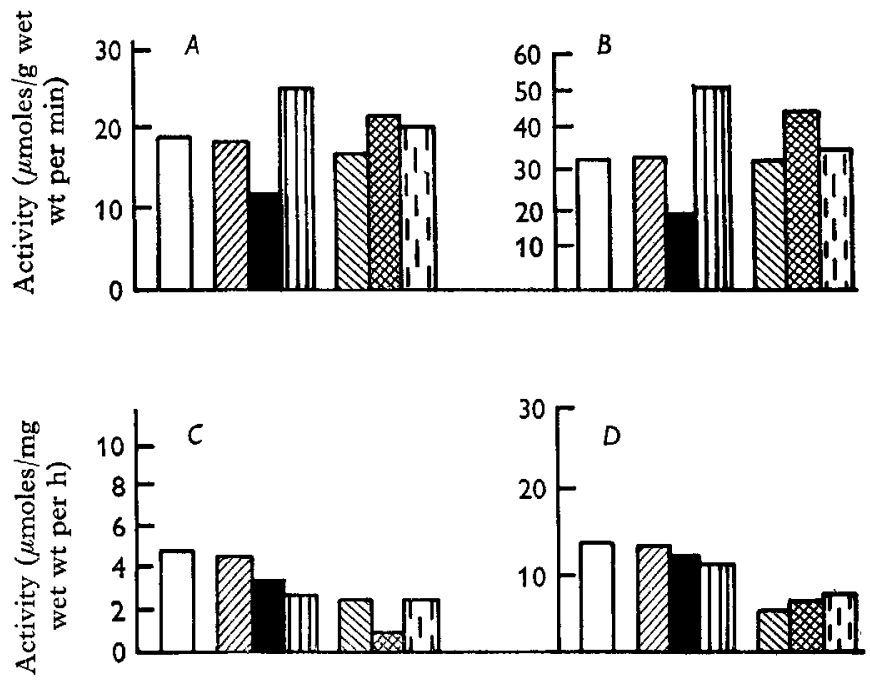

Fig. 2. Effect of protein-deficient diets on activities of $(A)$ lactase, $(B)$ maltase, $(C)$ glycylglycine and $(D)$ glycyl-leucine in jejunal mucosa of rats given different diets. $\square$, normal diet;

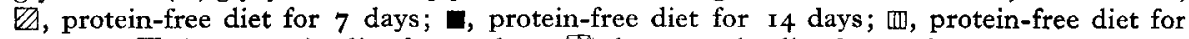
22 days; $\mathbb{\mathbb { N }}$, low-protein diet for 22 days; diet for 66 days.

That the increase in disaccharidase activities is probably an adaptive enzyme change is also borne out by the results for the dipeptidases. Both glycyl-glycine and glycyl-leucine dipeptidase activities consistently fell in rats on the low-protein or the protein-free diets (Table 7 and Fig. 2). This would be expected since the dietary protein providing the dipeptide substrates for these enzymes is diminished or disappears altogether.

That the changes in the enzymes resulting from feeding the animals on proteindeficient diets were not permanent can be seen from the results when rats that had previously been fed on these diets were given a normal diet (Table 8). After only 7 days on normal feeding, the disaccharidase activities had fallen to the mean normal; for the dipeptidase, the rise to normal values was, as might be expected, more gradual, 
the normal or even higher levels being reached only after 14 days on the normal diet. These results are again consistent with an adaptive enzyme change.

Aldolase was used as a reference enzyme since it is not so directly implicated in disaccharide or dipeptide absorption as the other enzymes studied (Table 6). As might be expected, there was little change in levels either on the low-protein or the protein-free diet up to 22 days, although there was a tendency for the activities to fall after longer periods on the low-protein diet. This applies to the enzyme activity with fructose-I-phosphate or fructose-I,6-diphosphate as substrate. Since alteration in substrate content could not affect the aldolase activity of the intestinal mucosa to the same extent as disaccharidase activity, the aldolase level would not be expected to increase to the same extent as did the disaccharidase. On the other hand, lack of nitrogen would tend to diminish enzyme synthesis, and the effect of these two opposing factors would seem to be little final alteration of enzyme activities except with longcontinuing deficiency of nitrogen.

It is difficult to explain the differences in the rate of increase of the activities towards the two substrates in animals fed on a normal diet after a long period on a low-protein one. Fructose-I,6-diphosphate activity returned to the normal level earlier than fructose-I-phosphate activity and rose thereafter to a greater level relative to the normal mean.

If the results of this investigation can be taken to exclude pure protein-calorie malnutrition as the cause of disaccharide intolerance in kwashiorkor, what then is the aetiology of this intolerance? Uncomplicated protein-calorie malnutrition seldom occurs, and the child almost always presents with gastroenteritis or a history of repeated past gastro-intestinal infection or infestation. Secondary or acquired disaccharide intolerance has been described as a result of gastroenteritis (Cevini et al. 1962; Sunshine \& Kretchmer, 1964), although no estimations of enzyme activity in the jejunal mucosa in these conditions have been made. It seems reasonable to assume that the gastro-intestinal infection in kwashiorkor is an important, if not the sole, factor in the causation of the disaccharide intolerance. This would be consistent with the low enzyme activities found by Stanfield et al. (1965) in their children with kwashiorkor. It is also possible that both protein-calorie deficiency and gastro-intestinal infection act together in inducing and prolonging disaccharide intolerance. Protein-calorie deficiency in pigs (Platt et al. 1964) itself produces changes in the mucosal epithelium, and gastrointestinal infection superimposed on this would be expected to result in more severe intolerance or enzyme deficiency than infection in a previously normal gut. Further evidence on this point is very desirable.

The speed of recovery of activity of the intestinal mucosal enzymes has interesting implications in the treatment of conditions of protein deficiency. If the results obtained can be applied to man, and if it is borne in mind that the shorter periods of time for the rat would correspond to much longer periods for the human infant, it appears likely that in kwashiorkor a diet normal in all respects can be tolerated fairly rapidly.

Further investigations on the effect of diarrhoea on enzyme activities of the intestinal mucosa in normal and malnourished rats are being undertaken. 
This research was mainly supported by the Research Funds of the Queen Elizabeth Hospital for Children. The cost of technical assistance was in part defrayed by the North East Metropolitan Regional Hospital Board. Dr G. Solimano gratefully acknowledges the receipt of a grant from the British Council, which enabled him to participate.

Thanks are due to Mr P. R. Payne of the Human Nutrition Research Unit, National Institute for Medical Research, whose advice in the preparation of the animal diets was essential, and to Mr V. G. Oberholzer for unstinted help.

\section{REFERENCES}

Alvarez, A. \& Sas, J. (1961). Nature, Lond. r9o, 826.

Bowie, M. D., Brinkman, G. L. \& Hansen, J. D. L. (1963). Lancet ii, 550.

Burgess, E. A., Levin, B., Mahalanabis, D. \& Tonge, R. E. (ro64). Archs Dis. Childh. 39, 43 r.

Cevini, G., Giovannini, M. \& Careddu, P. (1962). Minerva paediat. r4, 83 I.

Dean, R. F. A. (1952). Br. med. F. ii, 79 I.

Done, J. \& Payne, P. R. (1959). Wld Rev. Nutr. Diet. r, 227.

Heard, C. R. C. (1957). Proc. Nutr. Soc. 16, xl.

Josefsson, L. (1964). Nature, Lond. 204, 783 .

Josefsson, L. \& Lindberg, T. (I965a). Biochim. biophys. Acta ro5, I49.

Josefsson, L. \& Lindberg, T. (1965b). Biochim. biophys, Acta ro5, 162.

Levin, B., Oberholzer, V. G. \& Whitehead, T. P. (r950). Analyst 75, 561.

Leblond, C. P. \& Stevens, C. E. (1948). Anat. Rec. 100, 357.

Miller, D. S. \& Payne, P. R. (196r). F. Nutr. 74, 413.

Moore, S. \& Stein, W. H. (I948). F. biol. Chem. I76, 367.

Platt, B. S., Heard, C. R. C. \& Stewart, J. C. (1964). In The Role of the Gastrointestinal Tract in Protein Metabolism. A Symposium Organized by the Council for International Organizations of Medical Sciences Established under the Foint Auspices of UNESCO and WHO, p. 227. [H. N. Munro, editor.] Oxford: Blackwell Scientific Publications.

Stanfield, J. P., Hutt, M. S. R. \& Tunnicliffe, R. (1965). Lancet ii, 5 I9.

Sunshine, P. \& Kretchmer, N. (1964). Pediatrics, Springfield, 34, $3^{8}$. 